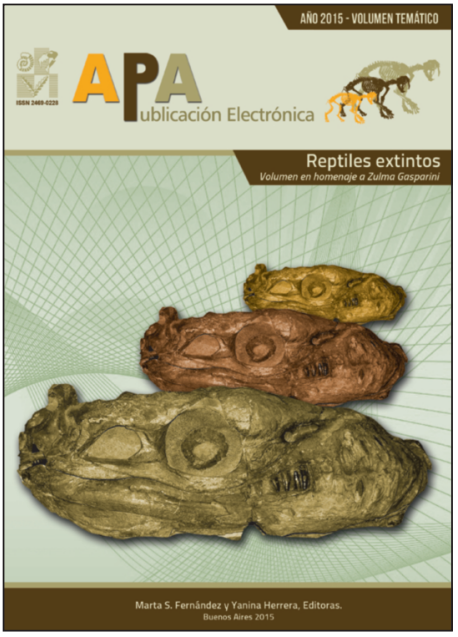

\title{
OPHTHALMOSAURIDS (ICHTHYOSAURIA: THUNNOSAURIA): ALPHA TAXONOMY, CLADES AND NAMES
}

MARTA S. FERNÁNDEZ $Z^{1,2}$

LISANDRO CAMPOS²

${ }^{1}$ CONICET.

2División Paleontología Vertebrados, Museo de La Plata, Universidad Nacional de La Plata, Paseo del Bosque s/n, B1900FWA La Plata, Argentina.

Recibido: 15 de junio 2015 - Aceptado: 25 de septiembre 2015

Para citar este artículo: Marta S. Fernández y Lisandro Campos (2015). Ophthalmosaurids (Ichthyosauria: Thunnosauria): alpha taxonomy, clades and names. En: M. Fernández y Y. Herrera (Eds.) Reptiles Extintos Volumen en Homenaje a Zulma Gasparini. Publicación Electrónica de la Asociación Paleontológica Argentina 15(1): 20-30.

Link a este artículo: http://dx.doi.org/10.5710/PEAPA.15.09.2015.96

DESPLAZARSE HACIA ABAJO PARA ACCEDER AL ARTí́CULO

Asociación Paleontológica Argentina Maipú $6451^{\circ}$ piso, C1006ACG, Buenos Aires República Argentina

Tel/Fax (54-11) 4326-7563 Web: www.apaleontologica.org.ar

Otros artículos en Publicación Electrónica de la APA 15(1):

\section{de la Fuente \& Sterli}

ESTADO DEL CONOCIMIENTO DE LAS TORTUGAS EXTINTAS DEL TERRITORIO ARGENTINO: UNA PERSPECTIVA HISTÓRICA.

\section{Paulina Carabajal}

GUIA PARA EL ESTUDIO DE LA NEUROANATOMÍA DE DINOSAURIOS SAURISCHIA, CON ENFASIS EN FORMAS SUDAMERICANAS.

\section{Pol \& Leardi}

DIVERSITY PATTERNS OF NOTOSUCHIA (CROCODYLIFORMES, MESOEUCROCODYLIA) DURING THE CRETACEOUS OF GONDWANA. 


\title{
OPHTHALMOSAURIDS (ICHTHYOSAURIA: THUNNOSAURIA): ALPHA TAXONOMY, CLADES AND NAMES
}

\author{
MARTA S. FERNÁNDEZ1,2 AND LISANDRO CAMPOS²
}

${ }^{1}$ CONICET.

2División Paleontología Vertebrados, Museo de La Plata, Universidad Nacional de La Plata, Paseo del Bosque s/n, B1900FWA La Plata, Argentina. martafer@fcnym.unlp.edu.ar; lisandrocampos1@gmail.com

\begin{abstract}
Thunnosaurian ichthyosaurs represent the paradigm of reptilian body designed for a pelagic life style. Most derived thunnosaurian, the ophthalmosaurids, have been traditionally considered as members of a declining lineage. New findings and the re-examination of historical collections radically changed our conceptions about them. Opthalmosaurids were ecologically more diverse than previously thought. The past few decades have seen an increase of nominal species spurred by new findings and analyses. A still unresolved problem is that many species are only known by their holotypes. Nevertheless, morphological disparity is a compelling argument for considering them as valid. All recent cladistic analyses of ichthyosaurs recover ophthalmosaurids as a clade. Neither the addition of new information nor the addition of new entities resulted in its collapse. On this basis, the assignment of Linnaean rank to this clade (Ophtalmosauridae) is reasonable as it satisfied the primary recommended criteria for taxa naming: monophyly and stability. As the lists of species and genus names are used as input in major data bases for interpreting major turnover and/or extinction patterns, efforts must be focused on clarifying as much as possible the alpha taxonomy. Two major pending issues are the delimitation of Ophthalmosaurus-Baptanodon, and Platypterygius. The case of Platypterygius is complex because the type species is poorly known, its holotype is lost, and there is no consensus among specialist about the species that should be included in this genus. On the other hand, we advocate for the use of the name Baptanodon natans instead of Ophthalmosaurus natans.
\end{abstract}

Key words. Ophthalmosaurids. Nominal species. Species delimitations.

Resumen. OFTALMOSÁURIDOS (ICHTHYOSAURIA: THUNNOSAURIA): TAXONOMÍA ALFA, CLADOS Y NOMBRES. Los ictiosaurios tunosaurios representan, entre los reptiles, el paradigma de la adaptación secundaria a la vida pelágica. Los tunosaurios más derivados, los oftalmosáuridos, han sido considerados tradicionalmente como miembros de un linaje en declive. Nuevos hallazgos, y la revisión de las colecciones históricas, cambiaron radicalmente nuestras concepciones acerca de ellos indicando que eran ecológicamente muy diversos. En las últimas décadas se ha producido un aumento de las especies nominales de oftalmosáuridos. Un problema aún no resuelto es que muchas especies solo son conocidas por sus holotipos. No obstante, la disparidad morfológica es un argumento de peso para considerarlas como válidas. Todos los análisis cladísticos recuperan a los oftalmosáuridos como un grupo monofilético. La adición de nueva información no provoca su colapso. Sobre esta base la asignación de rango linneano a este clado (Ophthalmosauridae) es razonable ya que cumple con los criterios recomendados para nombrar taxones: monofilia y estabilidad. Dado que las listas de especies y géneros se utilizan frecuentemente como datos básicos para interpretar patrones faunísticos y de extinción, los esfuerzos deben centrarse en aclarar lo más posible las listas taxonómicas. Dos temas pendientes son la delimitación de Ophthalmosaurus-Baptanodon y de Platypterygius. El caso de Platypterygius es complejo debido a que la especie tipo es poco conocida, su holotipo está perdido, y no hay consenso entre los especialistas sobre las especies que deben ser incluidas en él. Por otra parte, proponemos mantener el uso del nombre Baptanodon natans en lugar de Ophthalmosaurus natans.

Palabras clave. Oftalmosáuridos. Especies nominales. Delimitación de especies.

ICHTHYOSAURS were reptiles inhabiting the marine realm during most of the Mesozoic. Among them, thunnosaurians (ichthyosaurs with a fish-like profile and forefins much longer that the hindfins) represent the paradigm of reptilian body designed for a pelagic life style. The youngest and most derived thunnosauria clade, the ophthalmosaurids, includes all post-Bathonian forms except for a recently des- cribed basal non-ophthalmosaurid thunnosaurian from the late Hauterivian-Barremian (Early Cretaceous) of Kurdistan, Iraq (Fischer et al., 2013). Their records indicate a long evolutionary history ( 80 million years spanning from the Aalenian up to the Cenomanian), a rapid diversification, and a widespread distribution soon after the first appearance. Thus, the oldest record corresponds to a fragment of a fore- 
fin from the Aalenian/Bajocian boundary in Patagonia, Argentina (Fernández, 2003), and as early as the early Bajocian they are confidently documented in south-central Alaska (Druckenmiller and Maxwell, 2014). Since its first definition as a clade (Motani, 1999), the knowledge of ichthyosaurs in general and of ophthalmosaurids in particular has increased significantly. New findings and re-examination of historical collections have radically changed the traditional ideas about their low disparity, taxonomic and ecological diversities, and on their supposed decline since the Late Jurassic until their final extinction at the Cenomanian/Turonian boundary (Sander, 2000; Lingham-Soliar, 2003). Cladogenesis rate analyses suggest that, along its evolutionary history, the Aalenian and Kimmeridgian have been periods of intense speciation. These two periods were identified as 'Ophthalmosaurid' and 'Platypterygiine' radiations respectively (Fischer et al., 2013) (Fig. 1.1). This kind of macroevolutionary scenario rest upon input from the list of species recorded in each stage and/or the number of cladogenetic events resulting from time-calibrated cladograms. In both cases a central issue is the species concept/delimitation criteria used. The purpose of the present contribution is two fold. First, we provide an overview of the ophthalmosaurid species used in cladistic analyses and their occurrences. Second, we attempt to address a discussion on the current state of our knowledge of ophthalmosaurid taxonomic diversity highlighting topics of major consensus and the main pending issues.

\section{OPHTHALMOSAURIDS INCLUDED IN PHYLOGENETIC ANALYSES AND THEIR OCCURRENCE}

We use the informal term ophthalmosauria from a pragmatic point of view to include all ichthyosaurs that can be recognized by sharing a reduced extracondylar area of the basioccipital (see Druckenmiller and Maxwell, 2014, for definition of this character); angular largely exposed laterally, reaching as anteriorly as surangular; plate-like dorsal ridge on the humerus, extra zeugopodial element anterior to radius, and digit distal to it. Thus, we use ophthalmosauria for all the members of the clade supported by these synapomorphies (e.g., Motani, 1999; Fischer et al., 2013, 2014b; Fernández and Talevi, 2014; Roberts et al., 2014).

Twenty-two nominal ophthalmosaurian species have been recently considered as operative taxonomic units in cladistic analyses. A survey of their types and other specimens referred to ophthalmosauria at a species taxonomic level is presented below:

\section{Mollesaurus periallus Fernández, 1999}

The holotype of Mollesaurus periallus is the only known specimen of this bizarre monotypic genus. It represents the oldest diagnostic ophthalmosauria. Its holotype was collected in early Bajocian strata of the Los Molles Formation exposing in Neuquén Province, Argentina.

\section{Ophthalmosaurus icenicus Seeley, 1874}

This species -type species of the genus- is well known through abundant well-preserved specimens and available detailed descriptions (e.g., Andrews, 1910; Kirton, 1983). Most specimens were collected in the Oxford Clay (Callovian) exposing in southern England. Ophthalmosaurus cf. 0. icenicus has been recorded in Tithonian beds of the La Caja Formation, Coahuila, Mexico (Buchy, 2010).

\section{"Ophthalmosaurus" natans (Marsh, 1879)}

This species name has been traditionally used to include North American "Ophthalmosaurus" materials. It is known by several well-preserved specimens, including tridimensional articulated skulls. Most specimens were collected in the Oxfordian (Late Jurassic) of the Sundance Formation (US) (Massare et al., 2014), however its stratigraphic range is Callovian-Oxfordian.

\section{Brachypterygius extremus (Boulenger, 1904)}

Originally described on the basis of a single articulated forefin from the Kimmeridgian (Late Jurassic) of Dorset, England. For many years this material was the only one known until McGowan (1997) synonymized Grendelius mordax McGowan, 1976 to it. Grendelius mordax was originally described, and later on revised, on relatively complete skulls with diagnostic braincase elements (Kirton, 1983). McGowan and Motani (2003) proposed the survival of Brachypterygius into the Early Cretaceous based on the reassignment of Ichthyosaurus cantabrigiensis to this genus. However, a recent revision considered Brachypterygius cantabrigiensis as a non-valid name (Fischer et al., 2014C). 


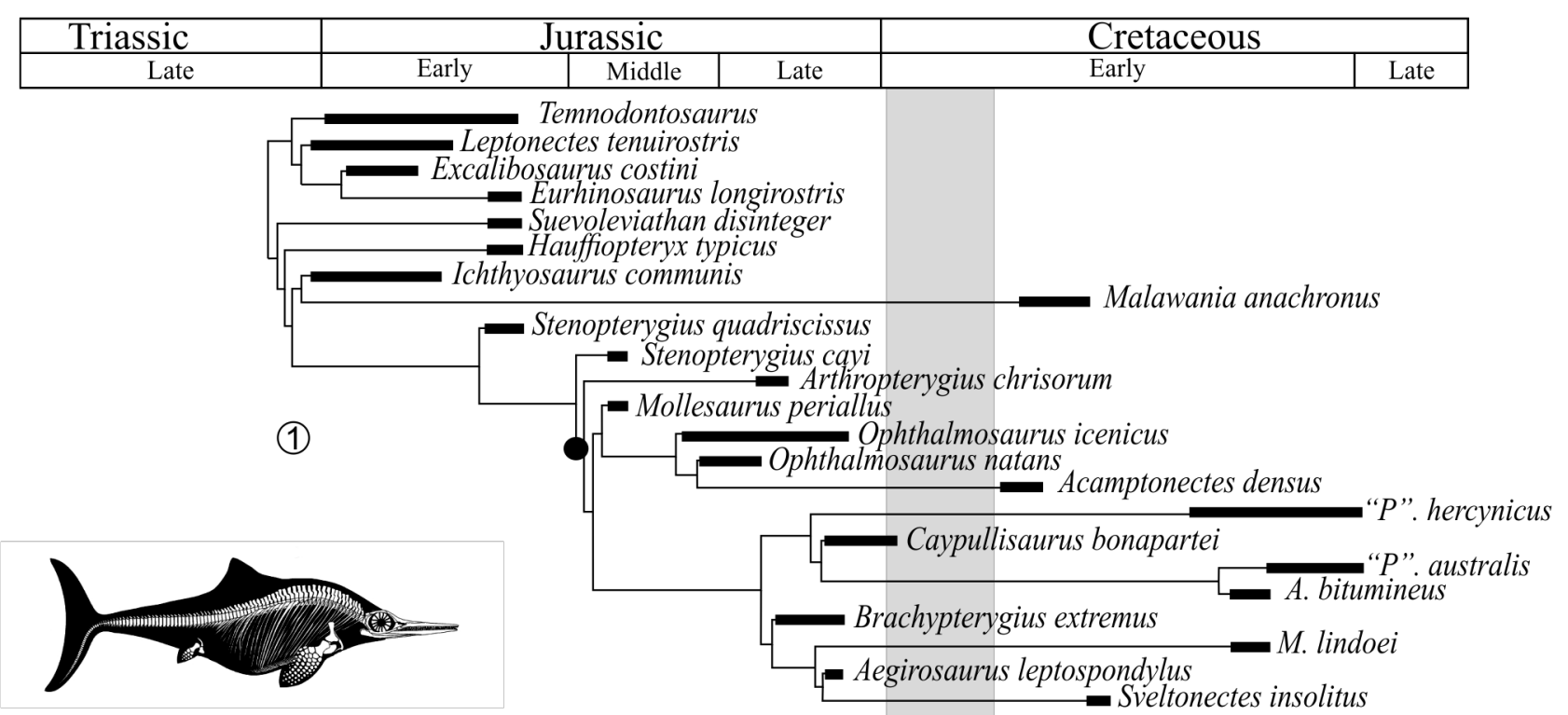

(2)
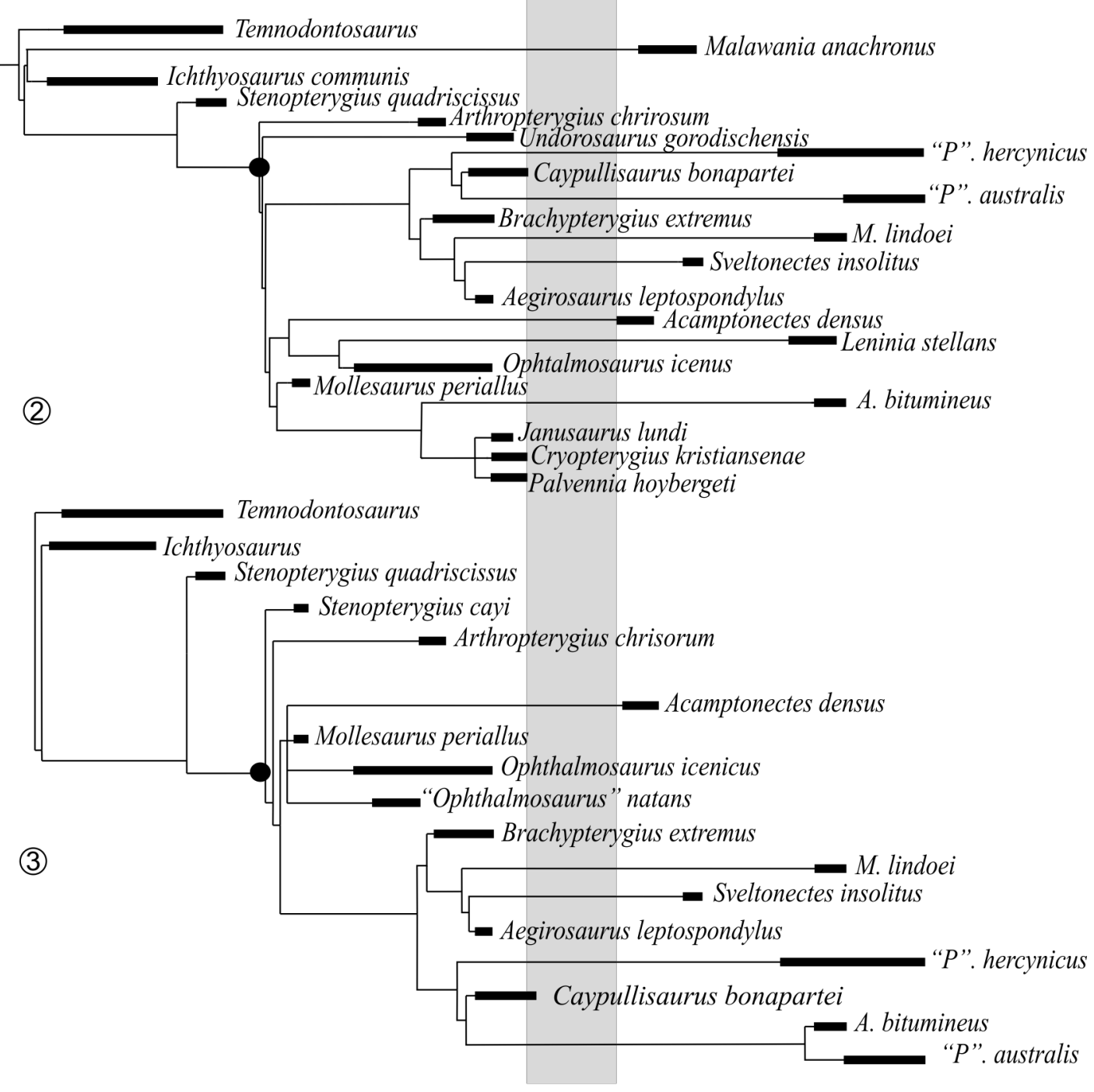


\section{Arthropterygius chrisorum (Russell, 1993)}

The genus Arthropterygius was proposed for Ophthalmosaurus chrisorum Russell, 1993, based on material recovered from the Ringnes Formation, Oxfordian to Kimmeridgian, Melville Island, Northwest Territories, Canada (Maxwell, 2010). The holotype, and other referred specimens, are incomplete and include braincase elements, fore- and hindfin and vertebrae. The holotype shows a peculiar modification of the internal carotid course piercing the posterior surface of the basisphenoid. Arthropterygius sp. were also collected in the Tithonian of the Vaca Muerta Formation (Argentina) and Middle Volgian of the Paromes Formation (Russia) (Fernández and Maxwell, 2012; Zverkov et al., 2015).

\section{Aegirosaurus leptospondylus (Wagner, 1853)}

The genus Aegirosaurus was proposed for Ichthyosaurus leptospondy/us, originally described based on material recovered from the lithographic limestones in Borscheim near Kelheim, Bavaria. As this specimen was destroyed during World War II, Bardet and Fernández (2000) selected as a neotype a complete and well-preserved specimen from the Solnhofen Formation, early Tithonian. A rostrum identified as Aegirosaurus sp. was collected in the Valaginian of southeastern France, extending the stratigraphic range of the genus to the Early Cretaceous (Fischer et al., 2010).

\section{Caypullisaurus bonapartei Fernández, 1997}

Type species of Caypullisaurus by monotypy. Its geographic and stratigraphic occurrence is currently restricted to the Tithonian-Berriasian of the Vaca Muerta Formation in the Neuquén Basin, Argentina. Pardo Pérez et al. (2011) tentatively identified with this species a few specimens from the Valanginian-Hauterivian (Early Cretaceous) from southern Chile. However, this identification has not been confirmed later (Stinnesbeck et al., 2014).

\section{Undorosaurus gorodischensis Efimov, 1999}

This is the type species of the genus and was described based on the specimens recovered from the middle Volgian of the Ul'yanovsk, Volga Region and Moscow Region, Russia. Two other species, U. khorlovensis and U. nessovi, originally assigned to this genus, were synonymized with the type species by McGowan and Motani (2003). Recently, Arkhangelsky and Zverkov (2014) described a new species, U. trautscholdi based on a partial forefin collected in the Volgian of Mnevniki, Moscow (Russia).

\section{Cryopterygius kristiansenae Druckenmiller, Hurum, Knutsen and Nakrem, 2012}

This is the only known species of the genus. Its holotype, and the only known material, is an almost complete and articulated skeleton collected in the Tithonian Agardhfjellet Formation in Svalvard (Norway).

\section{Palvennia hoybergeti Druckenmiller, Hurum, Knutsen and Nakrem, 2012}

This is the only known species of the genus. Its holotype, and only known specimen, consists of a complete skull and atlas-axis complex, a poorly preserved humerus and isolated distal limb elements; it was also collected in the Tithonian Agardhfjellet Formation of Svalvard (Norway).

Janusaurus Iundi Roberts, Druckenmiller, Saeter, and Hurum, 2014

This new taxon was based on a relatively complete holotype -and only known specimen- consisting of a skull lacking its most anterior tip, cervical, dorsal and caudal vertebrae, a pectoral girdle, forefin, partial pelvic girdle and both femora. It was collected in the Agardhfjellet Formation, early Middle Volgian (Late Jurassic).

Acamptonectes densus Fischer, Maisch, Naish, Kosma, Liston, Joger, Krüger, Pardo Pérez, Tainsh, and Appleby, 2012

The holotype of the only known species of the genus, including skull and axial skeleton, was collected in the Hau-

Figure 1. Time-callibrated phylogenetic relationships of ophthalmosaurid ichthyosaurs modified and simplified. 1, after Fischer et al. (2013); 2, after Roberts et al. (2014); 3, after Druckenmiller and Maxwell (2014). In grey: gap in the fossil record; black dot, Ophthalmosauria clade. 
terivian of the Speeton Clay Formation exposing in North Yorkshire, UK. A paratype was collected from the Hauterivian in Lower Saxony (Germany) extending the geographic range of this taxon.

\section{Sveltonectes insolitus Fischer, Masure, Arkhangelsky and Godefroit, 2011}

The holotype -and only known specimen- is an almost complete skeleton collected in the late Barremian (Early Cretaceous) in the Ul'yanovsk region, western Russia.

\section{Maiaspondylus lindoei Maxwell and Caldwell, 2006}

This species is known from the holotype and four paratypes (including remains of two embryos) collected in the middle Albian of the Northwest Territories of Canada.

\section{Athabascasaurus bitumineus Druckenmiller and Maxwell, 2010}

Athabascasaurus bitumineus was described based on its holotype -and only known specimen- collected in the Wabiskaw Member of the Clearwater Formation (early Albian), exposing in Alberta, Canada.

\section{Platypterygius platydactylus (Broili, 1907)}

The holotype of this species was destroyed during World War II. It is known from the original description and figures provided by Broili (1907). It consisted of skull, mandible, pectoral girdle and forefin, and most of the vertebral column. It was collected in the late Aptian of the Hannover area, Lower Saxony (Germany).

\section{Platypterygius americanus (Nace, 1939)}

This species is well known based upon well-preserved and tridimensional cranial and post-cranial remains. The horizon and type locality is the uppermost part of the Mowry Shale Member of the Graneros Formation (late Albian) in Wyoming (US). Reevaluation and revision of North American materials (Maxwell and Kear, 2010) confirmed its range extension up to the Cenomanian.

\section{Platypterygius australis (McCoy, 1867)}

This species is well-known by several well preserved specimens from Albian of Queensland, and the Albian-
Aptian in South Australia and the Northern Territory (Australia) (Zamit, 2010, 2012).

\section{Platypterygius hercynicus (Kuhn, 1946)}

The holotype, was recovered from the Aptian of Northern Harzvorland, Lower Saxony (Germany). This species name has been considered a synonym of P. platydactylus (McGowan and Motani, 2003). However later revisions of its holotype (Kolb and Sander, 2009) and of additional late Albian material from northwestern France (Fischer, 2012) resulted in a unique combination of features that warrant its recognition as a valid species name.

\section{Leninia stellans Fischer, Arkhangelsky, Uspensky, Stenshin and Godefroit, 2014a}

The holotype, and the only known specimen, consists of a well-preserved three-dimensional partial skull of an adult specimen collected in the early Aptian (Early Cretaceous) of the Kriushi locality, Sengiley district, Ul'yanovsk Region, Russia. Additional remains from the type locality have been mentioned as probably corresponding to this taxon but they were not formally assigned to it.

\section{Simbirskiasaurus birjukovi Ochev and Efimov, 1985}

The holotype -and the only known specimen- consists of a partial skull lacking the anterior most part of the snout and the postorbital region. It was collected in the early Barremian (Early Cretaceous) of the Ul'yanovsk area, Russia. Maisch and Matzke (2000) referred to it as Platypterygius birjukovi but Fischer et al. (2014a) re-analysed the holotype and considered Simbirskiasaurus birjukovi as valid.

\section{Pervushovisaurus bannovkensis Arkhangelsky, 1998}

The holotype -and the only known specimen- consists of a complete rostrum recovered from the Middle Cenomanian of the Nizhnaya Bannovka locality, Saratov Region, Russia.

Other nominal species traditionally considered as valid were not been yet included in phylogenetic analyses because they are represented by fragmented materials, i.e., "Platypterygius" campylodon (Carter, 1846); " $P$ ". hauthali (Huene, 1927); and Sisteronia seeleyi (Fischer et al., 2014a). Another species not included in phylogenetic analyses is 
Platypterygius sachicarum Páramo, 1997 from the early Aptian of Colombia (Hampe, 2005), which is known by the tridimentional skull of the holotype.

This brief survey highlights a problem that sometimes is overlooked. Of the 22 operative taxonomic units listed above, 11 are known only by their holotypes (Fig. 2).

\section{DISCUSSION}

\section{Alpha taxonomy and species delimitation}

Since the publication of the Handbook of Ichthyopterygia (McGowan and Motani, 2003) the number of nominal species of ophthalmosaurids has increased significantly. Thus, the amount of species considered as valid in 2003 (14 species within five genera) has increased up to at least 26 (the 22 taxa listed above plus Platypterygius campylodon, " $P$ ". sachicarum, "P". hauthali and Sisteronia seeleyi), included in 19 genera. This simple estimate highlights one of the main problems we are facing nowadays in the vertebrate paleontology, that is, the species delimitation. New debates on species concepts and delimitation have been triggered over the last decade in all major groups (e.g., plants, inverte- brates, and vertebrates). The cause of such debate has been the increase of species numbers and the so-called Taxonomic Inflation (e.g., Zachos, 2013, 2015; Bebber et al., 2014; Isaac et al., 2014). Although a debate on the species concept and species delimitation (de Queiroz, 2007) is beyond the scope of this contribution, a quick survey of scientific literature reveals that species delimitation in the last years has been a major concern among neontologists but not among paleontologists. It is obvious that, although species concept-species delimitation is a central issue for all of biology, assumptions and tools used in their recognition are different for extant and extinct forms. While the underlying assumption of interbreeding (i.e., biological species concept, Mayr, 1942) is a major concern for living forms, paleontologists can only assume arbitrarily the reproductive isolation of their "species". On the other hand, while "time of occurrence" is a central issue in paleontology, it needs no test in extant forms. Isaac et al. (2004) and Zachos (2013, 2015), among others, point out a shift in paradigm from the Biological Species Concept to various versions of the Phylogenetic Species Concepts as responsible of raising former

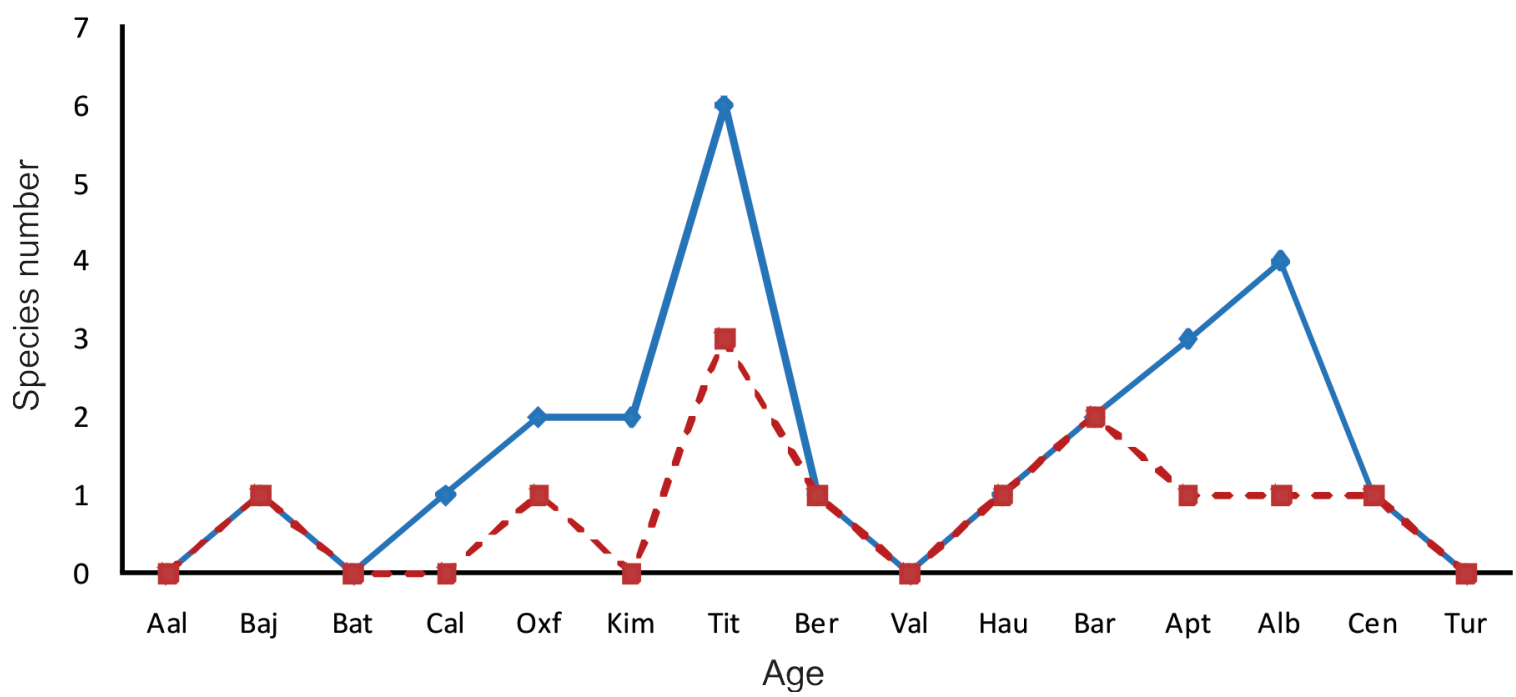

Figure 2. Operative taxonomic units (OTUs) of ophthalmosaurids (solid line), and OTUs only known by their holotypes (dash line) and their occurrences. Aal, Aalenian; Baj, Bajocian, Mollesaurus periallus; Bat, Bathonian; Cal, Callovian, Ophthalmosaurus icenicus; Oxf, Oxfordian, "O." natans, Arthropterygius chrisorum; Kim, Kimmeridgian, Brachypterygius extremus, Arthropterygius chrisorum; Tit, Tithonian, Aegirosaurus leptospondylus, Caypullisaurus bonapartei, Undorosaurus gorodischensis, Cryopterygius kristiansenae, Palvennia hoybergeti, Janusaurus lundi; Ber, Berriasian, Ca. bonapartei; Val, Valanginian; Hau, Hauterivian, Acamptonectes densus; Bar, Barremian, Sveltonectes insolitus, Simbirskiasaurus birjukovi; Apt, Aptian, Platypterygius platydactylus, Platypterygius hercynicus, Leninia stellans; Alb, Albian, Maiaspondylus lindoei, Athabascasaurus bituminous, P. americanus, P. australis; Cen, Cenomanian, Pervushovisaurus bannovkensis; Tur, Turonian. 
subspecies to species rank and, therefore, a risk for taxonomic inflation. In the particular case of mammals, Zachos $(2013,2015)$ remarked the significance -and potential undesirable impact- of taxonomic inflation not only for scientific knowledge but also for conservation policy, management and environmental legislation. Obviously, this is not the case in paleontology although, at a different scale, the last years have been also witness of an increase of nominal species, which in turn could result in a bias in the interpretations of major turnover and/or extinction patterns. In the particular case of ophthalmosaurid ichthyosaurs, the increase in the number of species does not seem to be a case of taxonomical inflation (i.e., "splitters" wining "lumpers" battle) but as a result of a real increase in the knowledge of morphological disparity within the group. Thus, certain regions of the ophthalmosaurian skeleton that have been traditionally considered as conservative, and therefore lacking information on the internal relationships of the clade, have demonstrated to be variable among terminal taxa. The widening of the zeugopodial region of the forefin by means of a preradial extra-zeugopodial element (clearly recognized as a synapomorphy of the group), and the humerus-zeugopodium articulation seems to be complex and morphologically more diverse than originally described (Fig. 3). The traditionally accepted "uninformative" nature of braincase elements (except the basioccipital) is also incorrect. Thus, change in the course of the internal carotids has been pointed out by Maxwell (2010) in the holotype of Arthropterygius chrisorum, and the same condition has been verified in materials from Patagonia (Fernández and Maxwell, 2012) and northern Russia (Zverkov et al., 2015). Exoccipital and stapes, which have been considered as non-informative for systematic
(1)

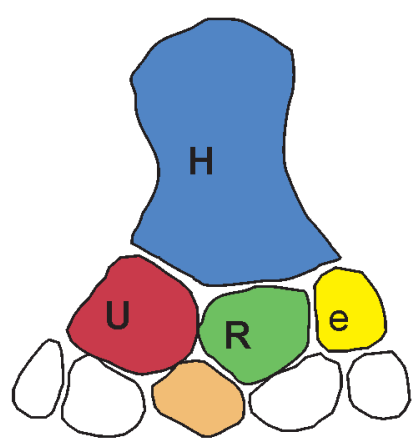

(4)

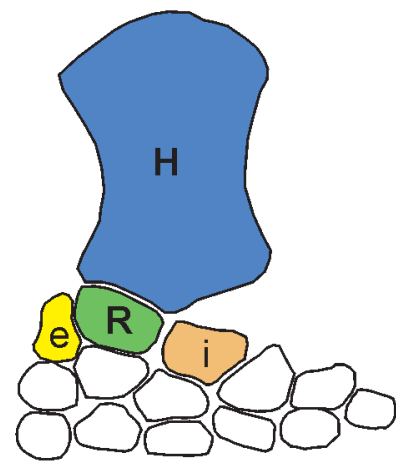

(2)

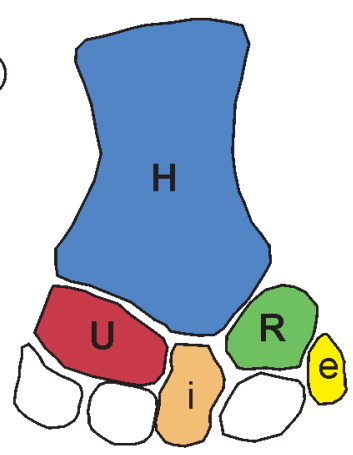

(5)

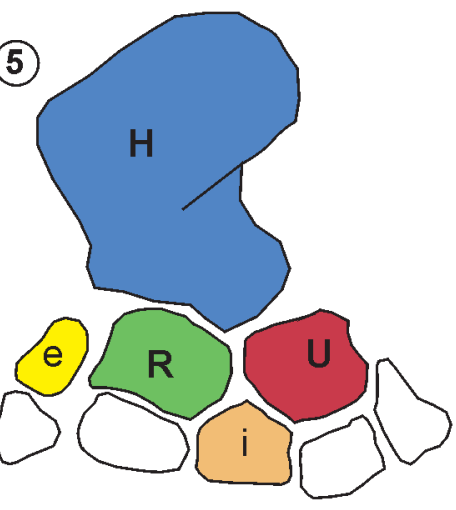

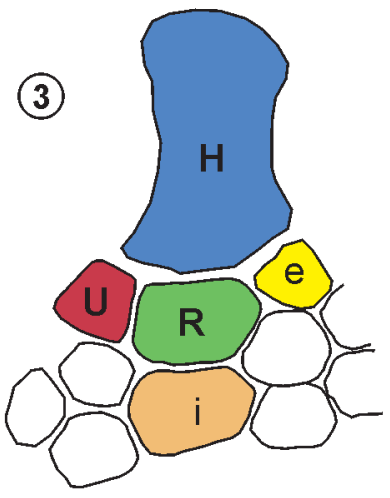

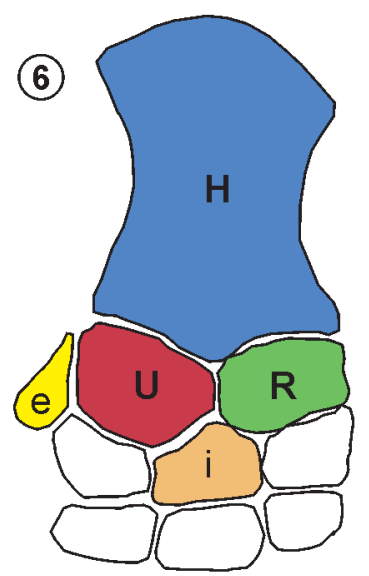

Figure 3. Proximal segments of ophthalmosaurid forefins showing the morphological diversity of the humero-zeugopodium articulation. 1 , Ophthalmosaurus icenicus; 2, Aegirosaurus leptospondylus; 3, Caypullisaurus bonapartei; 4, Sveltonectes insolitus; 5, Platypterygius australis; 6, P. americanus. 1-3, 6, right forefins, 4-5, left forefins. Not to scale. Abbreviations: e, extra-zeugopodial element; $\mathrm{H}$, humerus; i, intermedium; R, radius; U, ulna. 
proposes, also became a source of systematic useful characters (e.g., Fischer, 2012).

In summary, contrary to neontological cases, in which subspecies have been raised to species rank, in the case of ophthalmosaurids the increase in the number of species is the result of new findings (as is expected from paleontological explorations of new areas), and recognition of nominal species as valid. In other words, the increase from 14 up to 26 ophthalmosaurid species is the result of new findings (mainly from the northern high latitudes) and nomenclature decisions based on new morphological information.

A shortcut in the resolution of the species delimitation conflict in paleontology has been recently proposed by Silcox (2014) who advocated for a pragmatic approach. She suggested "...that paleontologists escape from the tyranny of the present and take a pragmatic approach to defining species that emphasizes what we actually need to do with them" (sic). In doing so, and close to the spirit of Cracraft's phylogenetic species concept (Cracraft, 1987), in the context of phylogenetic analysis species can be considered as the minimum diagnosable operational taxonomic units without any further requirement for testing "how those units came to be". According to the most extensive and recent phylogenetic analyses (Fischer et al., 2013; Roberts et al., 2014) all terminal units listed above can be considered as species as they are the minimum diagnosable units (e.g., Fischer et al., 2013: figs. S5-S7).

\section{Ophthalmosaurian, Ophthalmosauridae: clades and names}

Assuming these units as valid, the second step is the comparison of phylogenetic analyses available (Figs. 1, 4). Phylogenetic analyses consistently recovered ophthalmosauria (sensu Motani, 1999) as a clade, however decay index values are relatively low. Nevertheless, when highly incomplete taxa are prunned, ophthalmosauria branch support is relatively good (e.g., 6+, Fischer et al., 2013).

Although high values of branch support are always desirable it is worthy to remark that, in the case of advanced thunnosaurians, the identification of an Ophthalmosauria clade seems to be stable and robust. Crisci (1977) pragmatically defined the "best" biological classification as the one that is more stable, robust and, of course, predictive; understanding by stable the one that is not modified substantially by the addition of new information, robust if it is not modified by addition of new entities. Although the scientific context in which Crisci (1977) presented his contribution has changed, as cladistics has become the dominant paradigm in systematics, the statements exposed above are still valid. In the case of advanced thunnosaurians neither the addition of new characters (i.e., increase of character sampling) nor the addition of new entities (i.e., increase of taxon sampling) resulted in the collapse of ophthalmosauria clade. On this basis, the assignment of Linnaean rank to this clade (i.e., Ophthalmosauridae Baur, 1887 ) is reasonable as it satisfied the primary recommended criteria for taxa naming: monophyly and stability (Vences et al., 2013).

Within the ophthalmosauria clade, Fischer et al. (2012) recovered two subclades and named them as subfamilies Ophthalmosaurinae Baur, 1887, and Platypterygiinae Arkhangelsky, 2001. Stratigraphic calibration of their cladogram resulted in the recognition of two major radiations: Ophthalmosaurid Radiation in the Aalenian (Middle Jurassic) and a subsequent Platypterygiine Radiation at the Kimmeridgian (Late Jurassic) (Fischer et al., 2013). Based on the Fischer et al. $(2012,2013)$ data set and increasing taxon sampling, Druckenmiller and Maxwell (2014) and Roberts et al. (2014) results are congruent, recovering Ophthalmosaurinae and Platypterygiinae as monophyletic. However, the phylogenetic position of Athabascasaurus

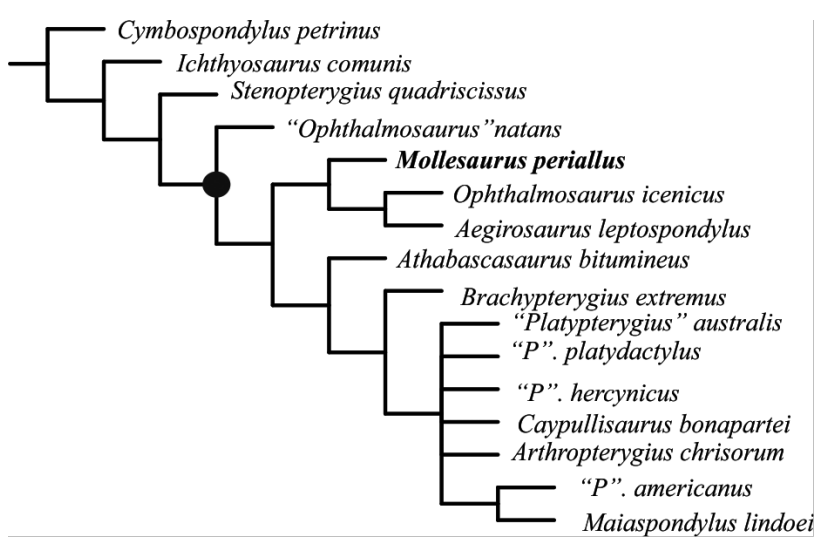

Figure 4. Phylogenetic relationships of ophthalmosaurid ichthyosaurs after Fernández and Talevi (2014). Black dot, Ophthalmosauria clade. 
bitumineus is contradictory among these analyses. While Fischer et al. (2013) and Druckenmiller and Maxwell (2014) found it as deeply nested within the platypteryiins; Roberts et al. (2014) recovered it as deeply nested within ophthalmosaurins. On the other hand, Fernández and Talevi (2014), based on the Druckenmiller and Maxwell (2010) data set, did not recover subclades within ophthalmosauria clade.

Descending in taxonomic hierarchical levels, a main problematic topic is the nomination of genera and species. This is more significant, not for the use of ichthyosaur specialists, but for researchers working on marine tetrapods in general. As advanced ichthyosaurs are considered as a paradigm of the secondary adaptation of tetrapods to marine life, their species/genus name lists and occurrences are candidates as raw data in integrative analyses on paleobiological diversity, fauna turn-overs and major extinction patterns (e.g., Benson and Druckenmiller, 2014; Kelley and Pyenson, 2015). Accepting pragmatically the list presented here as species, the next step is reaching a certain agreement on genus names. A main long overdue conflict is related with two names: Ophthalmosaurus Seeley, 1874, and Platypterygius Huene, 1922. Species included in the two genera are consistently recovered forming paraphyletic groups. "Platypterygius" case is complicated as the type species is poorly known, its holotype was destroyed during WW II, and there are several nominal species and no clear consensus on which species must be included within the genus (e.g., McGowan and Motani, 2003; Kolb and Sander, 2009; Zamit, 2010; Maxwell and Kear, 2010; Fischer, 2012). On the other hand, Ophthalmosaurus icenicus, the type species of Ophthalmosaurus Seeley, is well known and has been the main focus of a detailed and outstanding revision (Kirton, 1983). "Ophthalmosaurus" natans (Marsh, 1879), the other operative "Ophthalmosaurus" taxonomical unit and type species of Baptanodon Marsh, 1880, is also well known based on well preserved skull and postcranial materials, including the holotype (Massare et al., 2014). All recent phylogenetic analyses (Figs. 1,4) failed in finding Ophthalmosaurus icenicus + " $O$ ". natans as monophyletic so we find no reason to keep the last name combination instead of using Baptanodon natans (Marsh, 1879). In this way, a bit of confusion is avoided for non ichthyosaur specialist when using taxonomic lists.

\section{CONCLUSIONS}

In the light of the last decade discoveries and knowledge expansion, the conception of ophthalmosaurids as the youngest members of a declining lineage must be abandoned. However, from the brief survey provided herein several topics arise as not yet satisfactorily resolved, such as species known only by their holotype, the absence of Valanginian records identified at species level, and the lack of consensus on internal relationships of ophthalmosaurids. On the other hand, we are at a turning point in which morphological diversity knowledge is more compelling than taxonomic knowledge. Several ophthalmosaurid species are only known by their holotypes; nevertheless, morphological disparity among them and the other species allow distinguishing them as separate taxonomic units. Even considering that some names could eventually become synonyms, nomination of them as species avoid the risk of oversimplification -for non ichthyosaur specialists- using taxonomic lists for broad scale paleodiversity analyses. New fieldworks should fill the gaps in the fossil records and eventually help to test actual hypotheses on the species and genus delimitation and on internal relationships of ophthalmosaurid clade.

\section{ACKNOWLEDGMENTS}

This contribution is dedicated to a great leader of the Vertebrate Paleontology of South America, Prof. Dr. Zulma Gasparini. M.F. specially wants to thank Zulma for her warmly and constant support and advice not only as a Professor but, principally, as a human being during her carrier. This research was partially supported by the Agencia Nacional de Promoción Científica y Tecnológica (PICTs 2012-0748), CONICET (PIP 0433), and Programa de Incentivos N749, UNLP, Argentina. We are grateful to the reviewers (V. Fischer, and $\mathrm{M}$. Griffin), for their comments greatly improved the quality of this paper.

\section{REFERENCES}

Andrews, C.W. 1910. A descriptive catalogue of the marine reptiles of the Oxford Clay. Part I. British Museum (Natural History), London, $205 \mathrm{p}$.

Arkhangelsky, M.S. 1998. On the ichthyosaurian genus Platypterygius. Paleontological Journal 32: 611-615.

Arkhangelsky, M.S. 2001. On a new ichthyosaur of the genus Otschevia from the Volgian Stage of the Volga Region near Ul'yanovsk. Paleontological Journal 35: 629-634.

Arkhangelsky, M.S., and Zverkov, N.G. 2014. On a new ichthyosaur of the genus Undorosaurus. Proceedings of the Zoological Institute RAS 318: 187-196.

Bardet, N., and Fernández, M. 2000. A new ichthyosaur from the Upper Jurassic lithographic limestones of Bavaria. Journal of Paleontology 74: 503-511. 
Baur, G. 1887. On the morphology and origin of the Ichthyopterygia. American Naturalist 21: 837-840.

Bebber, D.P., Polaszek, A., Wood, J.R., Barker, C., and Scotland, R.W. 2014. Taxonomic capacity and author inflation. New Phytologist 202: 741-742.

Benson, R.B., and Druckenmiller, P.S. 2014. Faunal turnover of marine tetrapods during the Jurassic-Cretaceous transition. Biological Reviews 89: 1-23.

Boulenger, G.A. 1904. On new species of ichthyosaur from Bath. Proceedings of the Zoological Society of London 1904-1: 424426.

Broili, F. 1907. Ein neuer Ichthyosaurus aus der norddeutschen Kreide. Palaeontographica 54: 139-162.

Buchy, M.-C. 2010. First record of Ophthalmosaurus (Reptilia: Ichthyosauria) from the Tithonian (Upper Jurassic) of Mexico. Journal of Paleontology 84: 149-155.

Carter, J. 1846. On the ocurrence of a new species of Ichthyosaurus in the Chalk in the neighbourhood of Cambridge. Report of the British Association for the Advancement of Science 15: 60.

Cracraft, J. 1987. Species concepts and the ontology of evolution. Biology and Philosophy 2: 329-346.

Crisci, J.V. 1977. Clasificación biológica: naturaleza, objetivos, fundamentos. Obra del Centenario del Museo de La Plata 3: 51-61.

De Queiroz, K. 2007. Species concepts and species delimitation. Systematic Biology 56: 879-886.

Druckenmiller, P.S., and Maxwell, E.E. 2010. A new Lower Cretaceous (lower Albian) ichthyosaur genus from the Clearwater Formation, Alberta, Canada. Canadian Journal of Earth Sciences 47: 1037-1053.

Druckenmiller, P.S., and Maxwell, E.E. 2014. A Middle Jurassic (Bajocian) ophthalmosaurid (Reptilia, Ichthyosauria) from the Tuxedni Formation, Alaska and the early diversification of the clade. Geological Magazine 151: 41-48.

Druckenmiller, P.S., Hurum, J.H., Knutsen, E.M., and Nakrem, H.A. 2012. Two new ophthalmosaurids (Reptilia: Ichthyosauria) from the Agardhfjellet Formation (Upper Jurassic: Volgian/ Tithonian), Svalbard, Norway. Norwegian Journal of Geology 92: 311-339.

Efimov, V.M. 1999. A new family of Ichthyosaurs, the Undorasauridae fam.nov. from the Volgian Stage of the European part of Russia. Paleontological Journal 33: 174-181.

Fernández, M.S. 1997. A new ichthyosaur from the Tithonian (Late Jurassic) of the Neuquén Basin (Argentina). Journal of Paleontology 71: 479-484.

Fernández, M.S. 1999. A new ichthyosaur from the Los Molles Formation (early Bajocian), Neuquén basin, Argentina. Journal of Paleontology 73:677-681.

Fernández, M.S. 2003. Ophthalmosauria (Ichthyosauria) forefin from the Aalenian-Bajocian boundary of Mendoza Province, Argentina. Journal of Vertebrate Paleontology 23: 691-694.

Fernández, M.S., and Maxwell, E.E. 2012. The genus Arthropterygius Maxwell (Ichthyosauria: Ophthalmosauridae) in the Late Jurassic of the Neuquén Basin, Argentina. Geobios 45: 535-540.

Fernández, M.S., and Talevi, M. 2014. Ophthalmosaurian (Ichthyosauria) records from the Aalenian-Bajocian of Patagonia (Argentina): an overview. Geological Magazine 151: 49-59.

Fischer, V. 2012. New data on the ichthyosaur Platypterygius hercynicus and its implications for the validity of the genus. Acta Palaeontologica Polonica 57: 123-134.

Fischer, V., Appleby, R.M., Naish, D., Liston, J., Riding, J.B., Brindley, S., and Godefroit, P. 2013. A basal thunnosaurian from Iraq reveals disparate phylogenetic origins for Cretaceous ichthyosaurs. Biology Letters 9: 20130021. Doi: 10.1098/rsbl.2013.0021

Fischer, V., Arkhangelsky, M.S., Naish, D., Stenshin, I.M., Uspensky, G.N., and Godefroit, P. 2014a. Simbirskiasaurus and Pervushovisaurus reassessed: implications for the taxonomy and cranial osteology of Cretaceous platypterygiine ichthyosaurs. Zoological Journal of the Linnean Society 111: 822-841.

Fischer, V., Arkhangelsky, M.S., Uspensky, G.N., Stenshin, I.M., and Godefroit, P. 2014b. A new Lower Cretaceous ichthyosaur from Russia reveals skull shape conservatism within Ophthalmosaurinae. Geological Magazine 151: 60-70.

Fischer, V., Bardet, N., Guiomar, M., and Godefroit, P. 2014c. High diversity in Cretaceous ichthyosaurs from Europe prior to their extinction. PLOS ONE 9: e84709. Doi:10.1371/journal.pone. 0084709

Fischer, V., Clément, A., Guiomar, M., and Godefroit, P. 2010. The first definite record of a Valanginian ichthyosaur and its implications on the evolution of post-Liassic Ichthyosauria. Cretaceous Research 32: 155-163.

Fischer, V., Masure, E., Arkhangelsky, M.S., and Godefroit, P. 2011. A new Barremian (Early Cretaceous) ichthyosaur from western Russia. Journal of Vertebrate Paleontology 31: 1010-1025.

Fischer, V., Maisch, M.W., Naish, D., Kosma, R., Liston, J., Joger, U., Krüger, F.J., Pardo Pérez, J., Tainsh, J., and Appelby, R.M. 2012. New ophthalmosaurid ichthyosaurs from the european lower Cretaceous demonstrate extensive ichthyosaur survival across the Jurassic-Cretaceous boundary. PLOS ONE 7: e29234. Doi:10.1371/ journal.pone.0029234

Hampe, 0. 2005. Considerations on a Brachauchenius skeleton (Pliosauroidea) from the lower Paja Formation (late Barremian) of Villa de Leyva area (Colombia). Fossil record 8: 37-51.

Huene, F. v. 1922. Beitrag zur Kenntnis mariner mesozoicher Wirbeltiere in Argentinien. Zentralblatt für Mineralogie, Geologie und Paläontologie B: 22-29.

Huene, F. v. 1927. Beitrag zur Kenntnis mariner mesozoischer Wirbeltiere in Argentinien. Centralblatt für Mineralogie, Geologie und Paläontologie B: 22-29

Isaac, N.J., Mallet, J., and Mace, G.M. 2004. Taxonomic inflation: its influence on macroecology and conservation. Trends in Ecology \& Evolution 19: 464-469.

Kelley, N.P., and Pyenson, N.D. 2015. Evolutionary innovation and ecology in marine tetrapods from the Triassic to the Anthropocene. Science 348: aaa3716-1-aaa37161-7.

Kirton, A.M. 1983. [A review of British Upper Jurassic ichthyosaurs. Ph.D. Thesis, University of Newcastle upon Tyne, Newcastle upon Tyne, United Kingdom, 239 p. Unpublished.].

Kolb, C., and Sander, P.M. 2009. Redescription of the ichthyosaur Platypterygius hercynicus (Kuhn 1946) from the Lower Cretaceous of Salzgitter (Lower Saxony, Germany). Palaeontographica Abteilung 288: 151-192.

Kuhn, O. 1946. Ein skelett von Ichthyosaurus hercynicus n. sp. aus dem Aptien von Gitter. Berichte der Naturforschenden Gesellschaft Bamberg 29: 69-82.

Lingham-Soliar, T. 2003. Extinction of ichthyosaurs: a catastrophic or evolutionary paradigm? Neues Jahrbuch für Geologie und Paläontologie, Abhandlungen 228: 421-452.

Maisch, M.W., and Matzke, A.T. 2000. The Ichthyosauria. Stuttgarter Beiträge zur Naturkunde Serie B (Geologie und Paläontologie) 298: 1-159.

Marsh, O.C. 1879. A new order of extinct reptiles (Sauranodonta) from the Jurassic Formation of the Rocky Mountains. American 
Journal of Science, Series 3, 17: 85-86.

Massare, J.A., Wahl, W.R., Ross, M., and Connely, M.V. 2014. Palaeoecology of the marine reptiles of the Redwater Shale Member of the Sundance Formation (Jurassic) of central Wyoming, USA. Geological Magazine 151: 167-182.

Maxwell, E.E. 2010. Generic reassignment of an ichthyosaur from the Queen Elizabeth Islands, Northwest Territories, Canada. Journal of Vertebrate Paleontology 30: 403-415.

Maxwell, E.E., and Caldwell, M.W. 2006. A new genus of ichthyosaur from the Lower Cretaceous of Western Canada. Palaeontology 49: 1043-1052.

Maxwell, E.E., and Kear, B.P. 2010. Postcranial anatomy of Platypterygius americanus (Reptilia: Ichthyosauria) from the Cretaceous of Wyoming. Journal of Vertebrate Paleontology 30 : 1059-1068.

McCoy, F. 1867. On the occurrence of Ichthyosaurus and Plesiosaurus in Australia. Annals and Magazine of Natural History, Third Series 19: 355-356.

Mayr, E. 1942. Systematics and the origin of species, from the viewpoint of a zoologist. Harvard University Press, Cambridge, Massachusetts, $334 \mathrm{p}$.

McGowan, C. 1976. The description and phenetic relationships of a new ichthyosaur genus from the Upper Jurassic of England. Canadian Journal of Earth Sciences 13: 668-683.

McGowan, C. 1997. The taxonomic status of the Late Jurassic ichthyosaur Grendelius mordax: a preliminary report. Journal of Vertebrate Paleontology 17: 428-430.

McGowan, C., and Motani, R. 2003. Handbook of Paleoherpetology, Part 8 Ichthyopterygia. Verlag Dr. Friedrich Pfeil, Munich, 175 p.

Motani, R. 1999. Phylogeny of the Ichthyopterygia. Journal of Vertebrate Paleontology 19: 473-496.

Nace, R.L. 1939. A new ichthyosaur from the Upper Cretaceous Mowry Formation of Wyoming. American Journal of Science 237: 673-686.

Ochev, V.G., and Efimov, V.M. 1985. A new genus of Ichthyosaur from the UI'Yanovsk area of the Povolzh'ye Region. Paleontological Journal 4: 87-91.

Páramo, M.E. 1997. Platypterygius sachicarum (Reptilia, Ichthyosauria) nueva especie del Cretácico de Colombia. Revista Ingeominas 6: 1-12.

Pardo Pérez, J.M., Frey, E., Stinnesbeck, W., and Rivas, L. 2011. Early Cretaceous ichthyosaurs from the Tyndall Glacier in Torres Del Paine National Park, southernmost Chile. 72nd Annual Meeting of the Society of Vertebrate Paleontology (Las Vegas), Abstracts: 171.

Roberts, A.J., Druckenmiller, P.S., Sætre G-P., Hurum, J.H. 2014. A new Upper Jurassic ophthalmosaurid ichthyosaur from the Slottsmøya Member, Agardhfjellet Formation of Central Spitsbergen. PLOS ONE 9: e103152. Doi:10.1371/journal.pone. 0103152.

Russell, D.A. 1993. Jurassic marine reptiles from Cape Grassy, Melville Island, Arctic Canada. The Geology of Melville Island, Arctic Canada. Geological Survey of Canada Bulletin 450: 195-201.
Sander, P.M. 2000. The Ichthyosauria: their diversity, distribution, and phylogeny. Paläontologische Zeitschrift 74: 1-35.

Seeley, H.G. 1874. On the pectoral arch and forelimb of Ophthalmosaurus, a new ichthyosaurian genus from the Oxford Clay. Quaterly journal of the Geological Society of London 30: 696-707.

Silcox, M.T. 2014. A pragmatic approach to the species problem from a paleontological perspective. Evolutionary Anthropology 23: $24-26$.

Stinnesbeck, W., Frey, E., Rivas, L., Pérez, J.P., Cartes, M.L., Soto, C.S., and Lobos, P.Z. 2014. A Lower Cretaceous ichthyosaur graveyard in deep marine slope channel deposits at Torres del Paine National Park, southern Chile. Geological Society of America Bulletin: 1317-1339.

Vences, M., Guayasamin, J.M., Miralles, A., and De La Riva, I. 2013. To name or not to name: Criteria to promote economy of change in Linnaean classification schemes. Zootaxa 3636: 201-244.

Wagner, A. 1853. Die Characteristic einer neuen Art von Ichthyosaurus aus den lithographischen Schiefern und eines Zahnes von Polyptychodon aus dem Gründsandsteine von Kelheim. Bulletin der königlische Akademie der Wissenschaft, Gelehrte Anzeigen 3: 25-35.

Zachos, F.E. 2013. Species splitting puts conservation at risk. Nature 494: 35.

Zachos, F.E. 2015. Taxonomic inflation, the Phylogenetic Species Concept and lineages in the Tree of Life-a cautionary comment on species splitting. Journal of Zoological Systematics and Evolutionary Research 53: 180-184.

Zammit, M. 2010. A review of Australasian ichthyosaurs. Alcheringa 34: 281-292.

Zammit, M. 2012. Cretaceous Ichthyosaurs: Dwindling Diversity, or the Empire Strikes Back? Geosciences 2: 11-24.

Zverkov, N.G., Arkhangelsky, M.S., Pérez, J.P., and Beznosov, P.A. 2015. On the Upper Jurassic ichthyosaur remains from the Russian North. Proceedings of the Zoological Institute RAS 319: 81-97.

Recibido: 15 de junio 2015

Aceptado: 25 de septiembre 2015 